\title{
Analisa Pemanfaatan E-Learning Untuk Proses Pembelajaran
}

\author{
Nurlinda La Ucu ${ }^{1}$, Sary D.E. Paturusi ${ }^{2}$, Sherwin R.U.A Sompie ${ }^{3}$. \\ Teknik Informatika Universitas Sam Ratulangi Manado, Indonesia. \\ 13021106189@student.unsrat.ac.id ${ }^{1}$, sarypaturusi@unsrat.ac.id ${ }^{3}$, aldo@unsrat.ac.id².
}

\begin{abstract}
Abstrak - Keberadaan teknologi sudah tidak asing lagi dizaman modern ini, terutama dengan hadirnya berbagai media sosial dan situs jejaring sosial, yang dikenal dengan Facebook, Line, dan WhatsApp, yang dimana ketiga media sosial tersebut sangat banyak dikenal oleh masyarakat Indonesia pada umumnya. Salah satunya kehadiran media sosial tersebut sebagai teknologi komunikasi dan informasi maka dalam penerapannya lembaga pendidikan juga memanfaatkan media sosial tersebut sebagai media pembelajaran yang disebut E-Learning. E-Learning merupakan pembelajaran yang memanfaatkan teknologi, yaitu menggunakan media sosial, dimana pembelajaran E-Learning di Universitas De La Salle, Universitas Nusantara, dan STMIK Parna Raya juga telah memanfaatkan media sosial antara lain Facebook, Line, dan WhatsApp sebagai media pembelajaran. Dalam penelitian ini, metode yang digunakan yaitu deskriptif kualitatif dengan analisis statistik deskriptif, serta tujuan penelitian yaitu mengetahui keefektifan, penggunaan E-Learning, dan tingkat pemahaman terhadap pemanfaatan $E$ Learning di Universitas De La Salle, Universitas Nusantara, dan STMIK Parna Raya sebagai model pembelajaran dengan menggunakan media sosial Facebook, Line, Dan WhatsApp tersebut.
\end{abstract}

Kata Kunci : Media Sosial, E-Learning

\section{PENDAHULUAN}

Seiring perkembangannya Teknologi Informasi (TI) saat ini, lembaga pendidikan yaitu Universitas dalam penerapannya terhadap konsep belajar mengajar sudah berbasis TI. Konsep tersebut disebut sebagai $E$ Learning, E-Learning telah membawa pengaruh sehingga terjadinya transformasi terhadap pembelajaran konvensional (tradisional) ke bentuk digital (ELearning). Dimana E-Learning menyediakan berbagai platform yang berbasis web maupun dalam bentuk media sosial. Media sosial adalah salah satu media online yaitu para penggunanya dapat mencari informasi, berkomunikasi, dan menjalin pertemanan antar sesama pengguna dengan akun yang dimilikinya.

Universitas De La Salle berdiri pada tanggal 07 Agustus 2000 dengan mempunyai 5 (lima) Fakultas yaitu: Teknik, Ekonomi, Pertanian, Hukum, dan MIPA, dengan 10 (sepuluh) program studi. Sedangkan Universitas Nusantara berdiri pada tanggal 13 Juli 1995 dengan mempunyai 5 (lima) Fakultas yaitu: Teknik, Pertanian, Ilmu Komputer, Ekonomi, dan Sastra. Serta STMIK Parna Raya berdiri pada tanggal 02 Agustus 2001 dengan memiliki 3 (tiga) Program yaitu Program Sarjana (S1) yaitu: Teknik Informatika, Sistem Informasi, Sistem Komputer, Program Diploma (D3) yaitu: Manajemen Informatika, Teknik Komputer, dan Komputerisasi Akutansi, dan Program Diploma (D1) yaitu: Manajemen Informatika.

Berkaitan dengan implementasi pembelajaran yang berbasiskan teknologi informasi komunikasi yaitu $E$ Learning diketiga perguruan tinggi tersebut sebagai salah satu media pembelajaran alternatif dengan menggunakan media sosial dimana untuk mengukur keefektifan E-Learning serta pembelajaran konvensional sudah efektif atau belum. Hal ini, mengingat penggunaan media sosial sebagai alat tukar informasi yang sangat berpengaruh saat ini diberbagai kalangan khususnya kalangan mahasiswa serta tingkat kemudahan berbagi informasi juga sangat lancar, sehingga perlu adanya pemanfaatan E-Learning dengan menggunakan media sosial untuk menunjang pembelajaran konvensional yang ada.

Berdasarkan pada latar belakang yang dipaparkan diatas. Untuk itu, peneliti melakukan penelitian terhadap "Analisa Pemanfaatan E-Learning untuk Proses Pembelajaran", yaitu menggunakan media sosial Facebook, Line, dan WhatsApp, yang menunjang proses belajar dan mengajar sebagai media pembelajaran $e$ learning.

\section{LANDASAN TEORI}

\section{A. Analisis}

Analisis adalah penyampaian dalam suatu pokok atas berbagai bagiannya dan penelaahan bagian itu sendiri serta hubungan antar bagian untuk memperoleh pengertian yang tepat dan pemahaman arti keseluruhan [1].

B. Pemanfaatan

Pengertian pemanfaatan adalah aktivitas menggunakan proses dan sumber belajar [1]. 
a. Pengertian Media Pembelajaran

Kata media berasal dari bahasa latin dan merupakan bentuk jamak kata medium yang secara harfiah berarti perantara atau pengantar. Menurut Azhar Arsyad (2003:3), media adalah perantara atau pengantar pesan dari pengirim kepada penerima pesan. Media dalam proses belajar mengajar digunakan untuk memperlancar arus komunikasi antara pendidik dengan peserta didik [2].

\section{b. Efektivitas}

Dibawah ini merupakan beberapa pendapat terhadap keefektivitas sebagai berikut [3] :

1. Dalam Kamus Besar Bahasa Indonesia (2008: 352), efektivitas artinya keadaan berpengaruh atau hal berkesan.

2. Menurut Sadiman dalam Trianto (2009: 20), keefektifan pembelajaran yaitu hasil guna yang diperoleh setelah pelaksanaan proses belajar mengajar. Untuk mengetahui keefektifan mengajar dapat dilakukan dengan memberikan tes, karena hasil tes dapat dipakai untuk evaluasi berbagai aspek proses pengajaran.

\section{E-Learning}

Berikut beberapa para ahli menguraikan tentang definisi E-Learning dari berbagai sudut pandang sebagai berikut [4] :

1. Menurut Dong (Kamarga, 2002: 53) mendefinisikan bahwa E-Learning adalah kegiatan belajar asynchronous melalui suatu perangkat elektronik komputer yang dimana memperoleh bahan belajar sesuai dengan kebutuhannya.

2. Menurut Rosenberg (2001) menekankan bahwa $E$ Learning merujuk pada penggunaan teknologi internet untuk mengirimkan serangkaian solusi yang dapat meningkatkan pengetahuan dan keterampilan.

a. Karakteristik E-Learning

Dibawah ini merupakan karakteristik E-Learning antara lain [5] :

1. Memanfaatkan jasa teknologi elektronik, dimana guru dan siswa, sesama siswa, dan guru sesama guru dapat berkomunikasi dengan relatif mudah tanpa dibatasi oleh hal-hal yang protokoler.

2. Menggunakan bahan ajar bersifat mandiri (self learning materials) yang disimpan pada komputer sehingga dapat diakses oleh guru dan siswa kapan saja dan dimana saja bila yang bersangkutan memerlukannya.

\section{b. Pemanfaatan E-Learning}

Penggunaan E-Learning tidak bisa dilepaskan dengan peran Internet. Perkembangan pengguna internet di dunia ini berkembang sangat cepat karena beberapa hal sebagai berikut [2] :
1. Menggunakan internet adalah suatu kebutuhan untuk mendukung pekerjaan atau tugas sehari-hari.

2. Tersedianya fasilitas jaringan (Internet infrastructure) dan koneksi internet (Internet Connections)

3. Semakin tersedianya piranti lunak pembelajaran (management course tools).

4. Keterampilan jumlah orang yang mengoperasikan atau menggunakan internet.

c. Fasilitas E-Learning

Berikut dibawah ini merupakan fasilitas yang dimiliki E-Learning sebagai berikut [2] :

1. Pembelajaran dapat secara langsung dengan instruktur (synchronous) ataupun belajar secara individu (asynchronous).

2. Menggunakan elemen metode seperti kalimat dan gambar untuk mendistribusikan konten dan metode belajar.

3. Membangun wawasan dan teknik baru yang dihubungkan dengan tujuan belajar.

\section{Pembelajaran Konvensional}

Menurut Surakhmat (1980), metode ceramah adalah sebuah interaksi melalui penerangan dan penuturan secara lisan oleh seseorang terhadap sekelompok pendengar, misalnya penceramah (Penatar) dapat menggunakan alat bantu untuk menjelaskan uraiannya. Tetapi alat utama penghubungnya dengan kelompok pendengar (petatar) adalah bahasa lisan [4].

\section{E. Media Sosial}

Dibawah ini merupakan beberapa definisi media sosial sebagai berikut [6] :

1. Menurut Mandibergh (2012), media sosial adalah media yang mewakili kerja sama di antara pengguna yang menghasilkan konten (user generated content).

2. Menurut Shirky (2008), media sosial dan perangkat lunak sosial merupakan alat untuk meningkatkan kemampuan pengguna untuk berbagi (to share), bekerja sama (to-operate) di antara pengguna dan melakukan tindakan secara kolektif yang semuanya berada di luar kerangka institusional maupun organisasi.

F. Jenis Jejaring Sosial

a. Media Sosial Facebook

Facebook adalah salah satu situs jejaring sosial (social networking) dimana di dalam internet dapat memungkinkan pengguna (user) untuk berinteraksi dan berbagi data dengan pengguna lain. Social networking merupakan penggunaan sebuah website untuk menghubungkan orang-orang yang memiliki kesamaan minat personal dan profesional, tempat tinggal, pendidikan di sekolah tertentu dan lainnya [7]. 
Saat membuka grup, kita dapat memilih siapa yang dapat melihat grup dan kiriman dari anggota grup, termasuk komentar, foto, dan file yang diunggah ke grup. Siapa yang dapat melihat, mengunggah, dan mengunduh file bergantung pada pengaturan privasi grup. Adapun ketiga opsi privasi yang dapat dipilih sebagai berikut [7] :

1. Terbuka: Semua orang di Facebook dapat melihat dan bergabung dengan grup. grup akan muncul dalam hasil pencarian dan semua konten yang dikirim anggota (misalnya: foto, video, dan file) dapat dilihat oleh siapa saja yang mengunjungi grup.

2. Tertutup: Semua orang di Facebook dapat melihat nama grup, anggotanya, dan orang yang diundang bergabung di grup, tapi hanya anggota grup yang dapat melihat kiriman di dalam grup itu. Untuk bergabung dengan grup tertutup, kita harus ditambahkan atau meminta bergabung.

3. Rahasia: Grup ini tak dapat ditemukan dalam pencarian, dan non-anggota tidak dapat melihat apa pun tentang grup itu, termasuk nama dan daftar anggotanya. Nama grup tidak akan tampil dalam kronologi anggota.

b. Media Sosial Line

Aplikasi Line menggunakan sistem nomor telepon seluler penggunanya sebagai basis untuk saling berhubungan. Aplikasi Line saat ini tersedia untuk gadged yang memiliki sistem operasional iOS dan Android. Line berbeda dari aplikasi IM lainnya, karena ada emotikon yang bervariasi. Ada Emoji yang menggambarkan kepala dengan bermacam ekspresi, lalu emoticons berupa susunan karakter teks yang juga membentuk ekspresi, serta ada stickers. stickers ini yang cukup unik untuk Line, karena gambar ikonnya luculucu, berukuran besar dan lebih ekspresif. Sejak peluncuran pertamanya, pengguna Line di seluruh dunia mencapai 400 juta pengguna. Majalah SWA online menyebutkan bahwa pengguna Line kini digunakan lebih dari 170 juta pengguna aktif setiap bulannya. Jumlah pengguna aktif di Indonesia sebanyak 30 juta pengguna menempatkan negara Indonesia di posisi kedua pengguna Line terbanyak di dunia. Diantara fitur instant messaging Line yang sering digunakan sebagai berikut [8] :

1. Personal Chat. Fitur ini merupakan fitur utama yang diberikan oleh Line sebagai sarana komunikasi dengan pengguna Line lainnya secara private.

2. Share Foto atau Gambar Line memberikan fitur berbagai foto atau gambar baik secara personal melalui personal chat, ataupun melalui diskusi grup.

3. Free Call. Pengguna Line dapat menelpon pengguna Line lainnya dengan gratis karena menggunakan jaringan internet.

4. Sticker. Layaknya emoticon, sticker juga dapat digunakan untuk mengekspresikan sesuatu dengan bentuk dan gambar yang lebih besar, lebih lucu, dan lebih menarik.

5. Timeline Line. Menyediakan fitur timeline yang bisa digunakan untuk bersosial media layaknya timeline di Facebook.

6. Grup Line menyediakan fitur grup agar pengguna dapat berbincang-bincang dengan pengguna Line lebih dari satu pengguna.

c. Media Sosial WhatsApp

WhatsApp Messenger merupakan teknologi popular yang sangat potensial untuk dimanfaatkan sebagai alat pembelajaran. Al Saleem menambahkan bahwa dalam WhatsApp Messenger terdapat Whatsapp Group yang mampu membangun sebuah pembelajaran yang menyenangkan terkait berbagai topik diskusi yang diberikan oleh pengajar. Berikut dibawah ini merupakan fitur-fitur pada media sosial WhatsApp, sebagai berikut [9] :

1. Mengirim pesan teks

2. Mengirim foto dari galeri ataupun dari kamera

3. Mengirim video

4. Mengirimkan berkas-berkas kantor atau yang lainnya

5. Menelpon melalui suara, termasuk mengirim pesan suara yang dapat didengarkan oleh penerima setiap saat.

6. Berbagi lokasi memanfaatkan GPS

7. Mengirimkan kartu kontak

8. WhatsApp juga mendukung beberapa emotikon, namun untuk stiker, WhatsApp tergolong minimalis. Berbeda dengan Line yang lebih getol mengembangkannnya.

9. Di WhatsApp, pengguna juga dapat mengatur panel profilnya sendiri, terdiri dari nama, foto, status serta beberapa alat pengaturan privasi untuk melindungi profil dan juga alat bantuan untuk mem-backup pesan, mengubah nomor akun dan melakukan pembayaran.

\section{METODE PENELITIAN}

A. Populasi dan Sampel

a. Populasi

Menurut Sugiyono (2012: 117), populasi adalah wilayah generalisasi yang terdiri atas obyek dan subyek yang mempunyai kualitas dan karakteristik tertentu yang ditetapkan oleh peneliti dan kemudian ditarik kesimpulannya [10].

Populasi pada penelitian ini dilakukan pada mahasiswa, dan dosen di ketiga Universitas di Sulawesi Utara yaitu De La Salle dengan 200 responden, Universitas Nusantara dengan 150 responden, dan STMIK Parna Raya dengan 150 responden masingmasing di Fakultas teknik. 


\section{b. Sampel}

Sampel merupakan sebagian dari jumlah populasi yang dipilih untuk sumber data. Bila populasi besar maka peneliti tidak mungkin mempelajari semua yang ada pada populasi, misalnya karena keterbatasan dana, tenaga dan waktu, maka peneliti dapat menggunakan sampel yang diambil dari populasi itu [10].

Populasi pada penelitian ini lebih dari 100 orang, sehingga penentuan sampel dalam penelitian ini menggunakan teknik random sampling. Teknik random sampling ini memberi hak yang sama kepada semua siswa sebagai subjek dalam populasi untuk memperoleh kesempatan dipilih menjadi sampel penelitian (Sugiyono, 2012: 126). Teknik pengambilan sampel pada penelitian ini menggunakan rumus Slovin sebagai berikut [10] :

$\begin{array}{cl} & n=\frac{N}{1+N(e)^{2}} \\ \text { Keterangan : } & \mathrm{n}=\text { sampel } \\ & \mathrm{N}=\text { Jumlah populasi } \\ & \mathrm{e}=\text { tingkat kesalahan }\end{array}$

Berdasarkan dari rumus di atas, peneliti menentukan tingkat kesalahan sebesar 5\%, sehingga pengambilan sampel dalam penelitian ini yaitu :

$$
n=\frac{200}{1+200(0.05)^{2}}=133.33
$$

Perhitungan dengan menggunakan rumus slovin diatas, diketahui jumlah sampel yaitu 133.33 dibulatkan menjadi 133 sampel, maka dalam pengambilan sampel di De La Salle sebanyak 133 responden dengan jumlah populasi 133 responden di Fakultas Teknik. Sedangkan pada Universitas Nusantara dan STMIK Parna Raya jumlah sampel sebanyak 109.09 dibulatkan menjadi 109 sampel dari populasi 109 responden, seperti terlihat pada rumus dibawah ini.

$$
n=\frac{150}{1+150(0.05)^{2}}=109.09
$$

\section{B. Metode Pengumpulan Data}

Menurut Arikunto (1999: 151), metode pengumpulan data merupakan cara yang digunakan dalam mengumpulkan data penelitian. Untuk memperoleh data yang diinginkan sesuai dengan tujuan. Pengumpulan data dilakukan dengan menggunakan kuesioner (angket) dan sebagai berikut [7] :

\section{a. Kuesioner (Angket)}

Kuesioner atau angket merupakan sejumlah pertanyaan tertulis yang digunakan untuk memperoleh informasi dari responden dalam arti laporan tentang pribadinya atau hal-hal yang ia ketahui, instrumen ini menggunakan model skala sikap atau Skala Likert. Skala sikap disusun untuk mengukur sikap pro dan kontra, positif dan negatif, setuju dan tidak setuju terhadap suatu objek tertentu.

\section{b. Dokumentasi}

Menurut Arikunto, dokumentasi adalah metode yang digunakan untuk mencari data mengenai hal-hal atau variabel yang berupa catatan, transkrip, buku, surat kabar, majalah, prasasti, notulen rapat, lengger, agenda, dan sebagainya.

C. Analisa Data

a. Skala Pengukuran

Dalam penelitian ini, skala pengukuran yang digunakan ialah skala Likert. Menurut Kriyantono (2006:134), skala Likert merupakan skala yang digunakan untuk mengukur sikap, pendapat, dan persepsi seseorang atau kelompok orang tentang kejadian atau gejala sosial. Cara pengukurannya adalah dengan menghadapkan seorang reponden dengan sebuah pernyataan dan kemudian diminta untuk memberikan jawaban dari 5 (lima) pilihan jawaban tersebut. Dalam penelitian ini, digunakan petanyaan tertutup dengan rentang skala penilaian yaitu [11] :

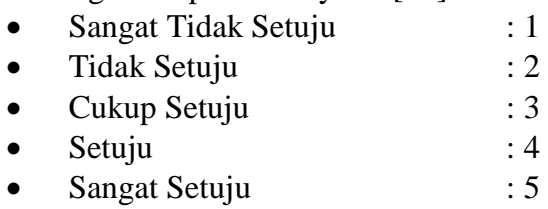

b. Analisis Tabulasi Sedehana

Dalam analisis tabulasi sederhana, data yang diperoleh diolah kebentuk presentase, dengan rumus sebagai berikut:

$$
\mathrm{P}=\frac{f i}{\sum f i} X 100 \%
$$

Dimana :

$\mathrm{P}=$ prsentasi responden yang memilih kategori tertentu $f i=$ jumlah responden yang memilih kategori tertentu $\sum f i=$ banyaknya jumlah responden

c. Skor Rata-rata

Setiap jawaban responden dari pertanyaan yang diberikan, diberi bobot. Cara menghitung skor adalah dengan menjumlahkan seluruh hasil kali nilai masingmasing bobotnya dibagi dengan jumlah total frekuensi. Rumus :

$$
\bar{x}=\frac{\sum f i \cdot w i}{\sum f i}
$$

Dimana :

$$
\begin{array}{ll}
\dot{\mathrm{X}}=\text { rata-rata berbobot } & \text { rat } \\
\mathrm{Fi} & =\text { frekuensi } \\
\mathrm{Wi} & =\text { bobot }
\end{array}
$$

Setelah itu, digunakan rentang skala penilaian untuk menentukan posisi tanggapan responden dengan menggunakan nilai skor setiap variabel. Bobot alternatif jawaban terbentuk dari teknik skala peringkat terdiri dari kisaran antara 1 sampai 5 yang menggambarkan 
posisi sangat negatif ke posisi yang positif. Selanjutnya dihitung rentang skala dengan rumus, sebagai berikut:

$$
R s=\frac{R(b o b o t)}{M}
$$

Dimana : R (bobot) $=$ bobot terbesar - bobot terkecil

$$
\mathrm{M} \quad \text { = banyaknya kategori bobot }
$$

Sehingga posisi keputusannya menjadi :

Tabel 3. 1. Kriteria skala sikap

\begin{tabular}{|l|l|}
\hline Skala & Keterangan \\
\hline $1,00-1,80$ & Sangat Tidak Efektif \\
\hline $1,80-2,60$ & Tidak Efektif \\
\hline $2,60-3,40$ & Cukup Efektif \\
\hline $3,40-4,20$ & Efektif \\
\hline $4,20-5,00$ & Sangat Efektif \\
\hline
\end{tabular}

D. Validitas dan Reliabilitas Penelitian

\section{a. Validitas}

Validitas berasal dari kata validity yang mempunyai arti sejauh mana ketepatan dan kecermatan. Sebelum instrumen digunakan untuk mengambil data, dilakukan terlebih dahulu pengujian untuk mengetahui valid dan tidaknya instrument. Instrumen dapat dikatakan valid apabila instrumen tersebut dapat digunakan untuk mengukur apa yang seharusnya diukur. Untuk mengukur kevalidan suatu instrument dapat menggunakan rumus Pearson/Product Moment [3].

\section{b. Reliabilitas}

Reliabilitas menunjukkan pengertian bahwa suatu instrumen cukup dapat dipercaya untuk dipergunakan sebagai alat pengumpul data karena instrumen sudah cukup baik, untuk menguji reliabilitas dapat menggunakan rumus Cronbach's Alpha. Dibawah ini merupakan keputusan dari interpretasi nilai reliabilitas [4].

Tabel 3. 2. Reliabilitas

\begin{tabular}{|l|l|}
\hline Koefisien Reliabilitas & Interpretasi \\
\hline $0.80-1.00$ & Sangat baik \\
\hline $0.60-0.80$ & Baik \\
\hline $0.40-0.60$ & Cukup \\
\hline $0.20-0.40$ & Buruk \\
\hline $0.00-0.20$ & Sangat buruk \\
\hline
\end{tabular}

\section{E. Responden Penelitian}

Responden penelitian dapat dibagi dalam beberapa karakteristik tergantung pada keperluan penelitian yang akan dilakukan.

1. Jenis Kelamin. Karakteristik akan menggambarkan dominasi populasi dalam lingkungan objek penelitian apakah didominasi oleh perempuan atau laki-laki.

2. Status/Pekerjaan. Karakteristik akan menggambarkan kedudukan baik mahasiswa dan dosen atau pegawai yang terlibat dalam lingkungan objek penelitian atau menggunakan objek penelitian.

3. Usia. Karakteristik ini menggambarkan usia dari responden yang tentunya bersangkutan dengan daya terima teknologi atau adaptasi terhadap sistem.

4. Masa kerja/Studi. Karakteristik ini menggambarkan sudah berapa lama si responden tersebut telah berada dalam lingkungan objek penelitian. Sehingga dari data ini dapat dihubungkan dengan pengalamannya mengamati/menggunakan objek penelitian.

5. Pengalaman menggunakan objek penelitian. Karakteristik ini menjelaskan tentang sudah berapa lama responden berurusan dengan objek penelitian. Semakin lama pengalamannya, maka akan semakin baik dan tepat penilaiannya.

\section{HASIL DAN PEMBAHASAN}

Pada penelitian ini peneliti melakukan pembahasan untuk menjawab pada rumusan masalah berdasarkan hasil penelitian terhadap penggunaan media sosial sebagai model pembelajaran E-Learning di berapa Universitas Sulawesi Utara antara lain Universitas De La Salle, Universitas Nusantara, dan STMIK Parna Raya

Berdasarkan 30 item pertanyaan di De La Salle dan Universitas Nusantara, serta 28 item pertanyaan di STMIK Parna Raya yang merujuk pada keterkaitan antara manusia dalam hal ini adalah mahasiswa, dosen, dan pegawai, teknologi yaitu media sosial (Facebook, Line, dan Whatsapp), dan organisasi yaitu Universitas terhadap pemanfaatan E-Learning sebagai model pembelajaran untuk mencapai suatu keefektifan, kemauan, kepuasan, dan kenyamanan selama proses pembelajaran.

Pemanfaatan teknologi sebagai model pembelajaran E-Learning dengan menggunakan media sosial Facebook, Line, dan Whatsapp menunjukan adanya keefektifan, kemauan, serta kepuasan belajar mahasiswa dengan dimilikinya akun-akun media sosial tersebut, yang mana penggunaan Facebook sebanyak 65 responden (De La Salle) dari 133 responden, 52 responden (UN) dari 109 responden dan 54 responden (STMIK Parna Raya) dari 109 responden, Line 30 responden (De La Salle) dari 133 responden, 20 responden (UN) 109 responden dan 22 (STMIK Parna Raya) responden dari 109 responden, dan Whatsapp 38 responden (De La Salle) dari 133 responden, 37 responden (UN) dari 109 responden dan 33 responden (STMIK Parna Raya) dari 109 responden. Dari data diatas dapat dikatakan bahwa ketiga Universitas ini menggunakan media sosial Facebook, Line, dan Whatsapp sebagai model pembelajaran E-Learning 
dimana dengan pengguna terbanyak pertama yaitu Facebook, dan terbanyak kedua yaitu Whatsapp, dan terbanyak ketiga Line dari ketiga Universitas tersebut. Berikut gambar dibawah ini adalah tingkat penggunaan media sosial.

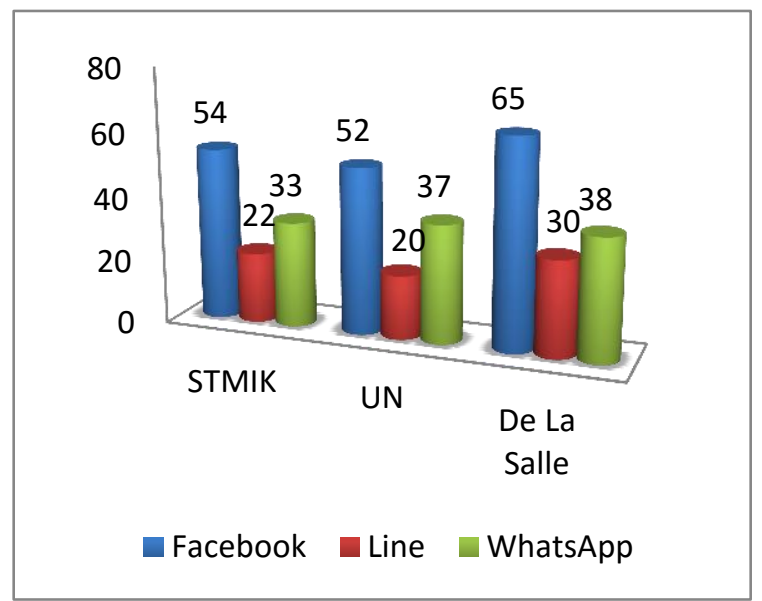

Gambar 4. 1. Perbedaan Penggunaan Media Sosial

Sumber : hasil analisis penulis

1. Keefektifan pembelajaran E-Learning dan Konvensional di Universitas De $\mathrm{La}$ Salle, Universitas Nusantara, dan STMIK Parna Raya.

Berdasarkan pada hasil analisis dapat diketahui bahwa keefektifan dalam pembelajaran E-Learning di Universitas Sulawesi Utara yaitu De La Salle, Universitas Nusantara, dan STMIK Parna Raya sudah efektif dalam menerapkan pembelajaran E-Learning maupun pembelajaran konvensional. Dimana kedua model pembelajaran tersebut yaitu E-Learning dan konvensional sama-sama disukai oleh mahasiswa maupun dosen, salah satunya dengan memberikan sikap atau penilaian positif terhadap kedua pembelajaran tersebut.

Dalam penerapan pembelajaran E-Learning dengan menggunakan media sosial Facebook, line, dan WhatsApp, dapat dilihat kualitas sistem E-Learning-nya sudah efektif dengan skor rata-rata tertinggi 3.95 di De La Salle, skor rata-rata tertinggi 4.09 di Universitas Nusantara, serta skor rata-rata tertinggi 4.06 di STMIK Parna Raya. Sedangkan kualitas informasi terhadap ELearning juga sudah efektif dengan skor rata-rata tertinggi 3.97 di De La Salle, skor rata-rata tertinggi 4.19 di Universitas Nusantara, dan di STMIK Parna Raya dengan skor rata-rata tertinggi 4.09. Berikut dapat dilihat pada gambar dibawah ini.

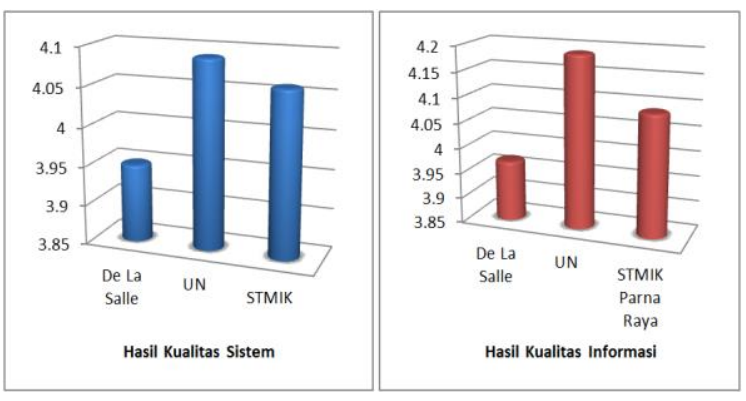

Gambar 4. 2. Kualitas Sistem E-Learning dan Kualitas Sumber : hasil analisis penulis Informasi E-Learning

Selain itu, aktivitas pembelajaran konvensional sudah efektif, hal ini dapat dilihat dari skor rata-rata tertinggi 3.94 di De La Salle, skor rata-rata tertinggi 4.07 di Universitas Nusantara, dan skor rata-rata tertinggi 4.09 di STMIK Parna Raya. Sedangkan informasi pembelajaran konvensional juga sudah efektif di ketiga Universitas tersebut, dengan skor rata-rata tertinggi 3.81 di De La Salle, skor rata-rata tertinggi 3.88 di Universitas Nusantara, dan skor rata-rata tertinggi 3.94 di STMIK Parna Raya. Berikut dapat dilihat pada gambar dibawah ini.

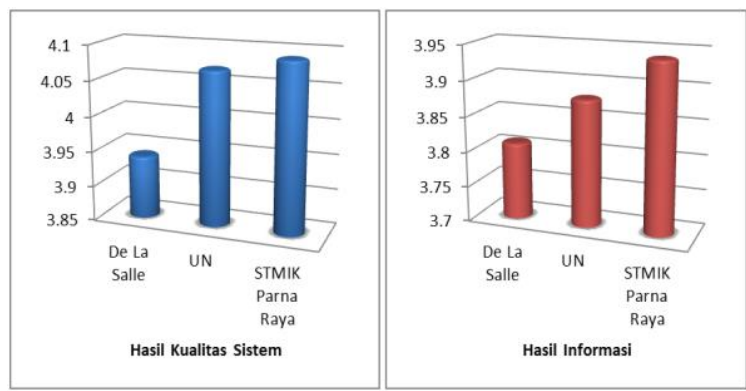

Gambar 4. 3. Kualitas Sistem dan Informasi Terhadap Pembelajaran Konvensional Sumber : hasil analisis penulis

2. Penggunaan pembelajaran E-Learning dapat menggantikan pembelajaran konvensional

Berdasarkan hasil data yang dianalisa bahwa pembelajaran E-Learning tidak menggantikan pembelajaran konvensional, melainkan kedua model pembelajaran ini sama-sama digunakan atau diterapkan di Universitas De La Salle, Universitas Nusantara, dan STMIK Parna Raya, yang mana apabila dosen tidak dapat hadir mengikuti kelasnya maka dosen tersebut dapat menggunakan kelas E-Learning untuk membagikan atau upload materi tersebut, atau tugastugas lainnya dan mahasiswa pun dapat mengambil materi dan tugas yang dibagikan oleh dosen tersebut. Dapat dilihat pada penggunaan E-Learning dengan skor rata-rata tertinggi 3.80 di Universitas De La Salle, skor rata-rata tertinggi 3.88 di Universitas Nusantara, serta skor rata-rata tertinggi 4.09 di STMIK Parna Raya. 
Sedangkan pembelajaran konvensional dengan skor rata-rata tertinggi 3.81 di Universitas De La Salle, skor rata-rata tertinggi 4.05 di Universitas Nusantara, serta skor rata-rata tertinggi 4.04 di STMIK Parna Raya. Berikut dapat dilihat pada gambar dibawah ini.

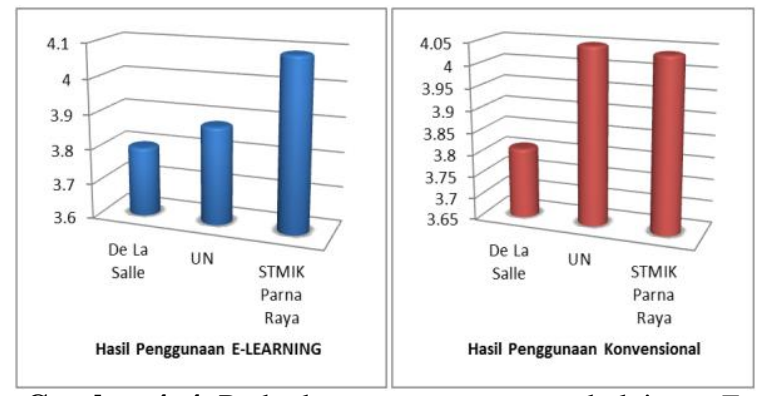

Gambar 4. 4. Perbedaan penggunaan pembelajaran $E$ Learning dan pembelajaran konvensional Sumber : hasil analisis penulis

3. Tingkat pemahaman mahasiswa terhadap ELearning dan pembelajaran konvensional.

Pemahaman mahasiswa terhadap pelajaran yang diberikan oleh dosen selama proses belajar berlangsung merupakan tujuan dari dosen atas berhasilnya suatu pembelajaran tersebut baik itu pembelajaran melalui E-Learning maupun pembelajaran konvensional. Dalam pemahaman mahasiswa terhadap pembelajaran E-Learning dapat dilihat berdasarkan skor rata-rata tertinggi 3.75 di De La Salle, skor rata-rata tertinggi 4.05 di Universitas Nusantara, dan skor ratarata tertinggi 3.95 di STMIK Parna Raya. Sedangkan pembelajaran konvensional dengan skor rata-rata tertinggi 4.00 di De La Salle, skor rata-rata tertinggi 4.01 di Universitas Nusantara, dan skor rata-rata tertinggi 3.95 di STMIK Parna Raya. Berikut dapat dilihat pada gambar dibawah ini.

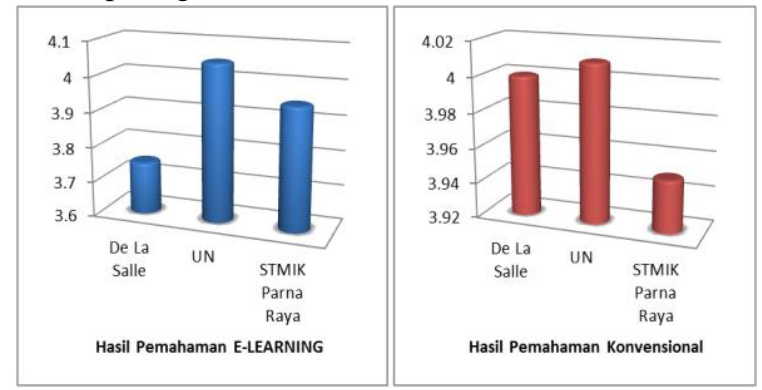

Gambar 4. 5. Pemahaman E-Learning dan pembelajaran konvensional

Sumber : hasil analisis penulis

\section{KESIMPULAN DAN SARAN}

\section{A. KESIMPULAN}

Dari hasil analisis penelitian yang dilakukan mengenai pemanfaatan E-Learning untuk proses pembelajaran menggunakan media sosial Facebook, Line, dan WhatsApp di De La Salle, Universitas Nusantara, dan STMIK Parna Raya dapat disimpulkan bahwa :

1. De La Salle, Universitas Nusantara, dan STMIK Parna Raya sudah menerapkan pembelajaran $E$ Learning dengan menggunakan media sosial Facebook, Line, dan WhatsApp untuk menunjang proses berlangsungnya pembelajaran, sehingga adanya interaksi antar mahasiswa dan mahasiswa, mahasiswa dan dosen.

2. Dalam penerapan pembelajaran E-Learning di De La Salle, Universitas Nusantara, dan STMIK Parna Raya juga sudah efektif. Maksudnya, kedua model pembelajaran E-Learning dan konvensional tersebut sama-sama efektif.

3. Kualitas sistem dan informasi terhadap E-Learning di Universitas Nusantara sangat tinggi, untuk STMIK Parna Raya dari kedua hasil tersebut berada pada posisi kedua, sedangkan De La Salle berada pada posisi ketiga.

4. Penggunaan E-Learning di STMIK Parna Raya sangat tinggi, untuk Universitas Nusantara berada pada posisi kedua, sedangkan De La Salle berada pada posisi ketiga. Pada penggunaan pembelajaran konvensional di Universitas Nusantara sangat tinggi, untuk STMIK Parna Raya berada pada posisi kedua, dan De La Salle berada pada posisi ketiga.

5. Pemahaman E-Learning di Universitas Nusantara sangat tinggi, untuk STMIK Parna Raya berada pada posisi kedua, dan De La Salle berada pada posisi ketiga, sedangkan pemahaman konvensional di Universitas Nusantara sangat tinggi, untuk De La Salle berada pada posisi kedua, dan STMIK Parna Raya berada pada posisi ketiga.

\section{B. SARAN}

E-Learning dan pembelajaran konvensional diketiga perguruan tinggi tersebut sudah efektif, sehingga dalam penerapannya lebih ditingkatkan lagi pengawasannya dalam pembelajaran salah satunya dengan membentuk kelas E-Learning yang bertatap muka (konvensional) yang dapat digunakan untuk membahas berbagai adanya kendala-kendala yang ada dan tidak bisa diselesaikan digrup E-Learning tersebut.

\section{DAFTAR PUSTAKA}

[1]. Sutiyono, dkk, 2013. Analisis Pemanfaatan ELearning Sebagai Media Pembelajaran Di Universitas Diponegoro. Fakultas Ilmu Komputer. Program Studi Teknik Informatika. Universitas Bina Darma. Palembang.

[2] Fremaditiya Tondy, 2012. Pengaruh Pemanfaatan Media E-Learning Dan Lingkungan Belajar Terhadap Kreativitas Siswa Pada Mata Pelajaran TIK Kelas Viii Di SMPN 1 Gamping. Fakultas 
Teknik. Program Studi Pendidikan Teknik Informatika. Universitas Negeri Yogyakarta. Yogyakarta.

[3] Arianita Keke, 2013. Efektivitas Model Pembelajaran Inkuiri Dalam Meningkatkan Keaktifan Dan Prestasi Belajar Siswa Pada Mata Pelajaran Ekonomi Kelas X Sma Negeri 1 Kasihan Kabupaten Bantul Tahun Ajaran 2012/2013. Fakultas Ekonomi. Program Studi Pendidikan Ekonomi Universitas Negeri Yogyakarta. Yogyakarta.

[4] Utomo Feby Widhi Setyo, 2013. Perbedaan Minat Belajar Siswa Dengan Menggunakan Model Pembelajaran E-Learning Dan Konvensional Pada Mata Pelajaran Sejarah Di SMA N 1 Candiroto Temanggung. Fakultas Ilmu Sosial. Jurusan Sejarah. Universitas Negeri Semarang. Semarang.

[5] Yazdi Mohammad, 2012. E-Learning Sebagai Media Pembelajaran Interaktif Berbasis Teknologi Informasi. Fakultas Matematika Dan Ilmu Pengetahuan Alam. Universitas Tadulako.

[6] Fitrianur Irfan, 2016. Analisis Efek Penggunaan Media Sosial Line Messenger Pada Remaja Di Smk Negeri 1 Samarinda.

[7] Anggara Agung Meisa, 2013. Pemanfaatan Jejaring Sosial Melalui Grup Dalam Facebook Sebagai Sarana Pengelolaan Pembelajaran Pada Mata Pelajaran Teknologi Informasi Dan Komunikasi Kelas X Sma. Fakultas Teknik. Jurusan Teknik Elektro Universitas Negeri Semarang.

[8] Irianto Bimbing Roby, dkk, 2015. Pengaruh Penggunaan Instant Message Line Terhadap Efektifitas Komunikasi Interpersonal. Fakultas Ilmu Komunikasi Dan Bisnis. Universitas Telkom.

[9] Jumiatmoko, 2016. Whatsapp Messenger dalam Tinjauan Manfaat Dan Adab. Madina Sragen.

[10] Herlambank Muhhamad Azyes, 2015. Hubungan Penggunaan Media Pembelajaran Edmodo Dengan Hasil Belajar Siswa Pada Pelajaran Simulasi Digital Di Smk Negeri 1 Gombong. Fakultas Teknik. Program Studi Pendidikan Teknik Informatika. Universitas Negeri Yogyakarta. Yogyakarta.

[11] Larasati Widya, dkk, 2013. Efektivitas Pemanfaatan Aplikasi Whatsapp Sebagai Sarana Diskusi Pembelajaran Pada Mahasiswa. Fakultas Ilmu Sosial dan Humaniora Uin Sunan Kalijaga Yogyakarta.

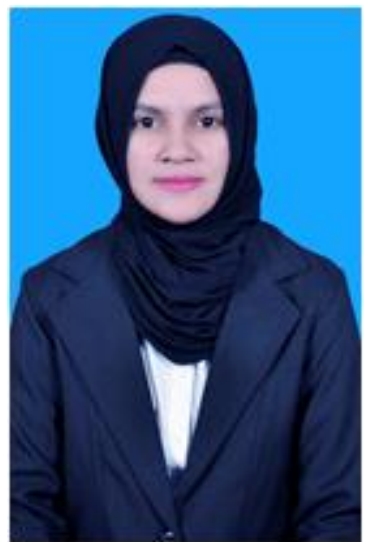

Nurlinda La Ucu

Lahir di Jikohay pada tanggal 26 Oktober 1995, dari pasangan suami/istri Bapak La Ucu dan Ibu Safia, Anak Pertama dari lima orang bersaudara. Penulis bertempat tinggal tepatnya di Desa Jikohay, Kecamatan Obi Barat, Halmahera Selatan. Adapun riwayat pendidikan penulis yaitu Sekolah Dasar di SD Inpres Jikohay pada tahun 2001-2007, lalu melanjutkan pendidikan Sekolah Menengah Pertama di SMPN 4 Obi pada tahun 2007-2010, kemudian melanjutkan pendidikan di Sekolah Menengah Atas yaitu SMA LPM Jikohay pada tahun 2010-2013. Pada tahun 2013 penulis melanjutkan pendidikan ke Perguruan Tinggi di Universitas Sam Ratulangi Manado. Dengan mengambil Jurusan Elektro Program Studi Teknik Informatika.

Pada tanggal 26 September 2016 penulis melakukan Kerja Praktek di Kantor Lurah Bahu Manado, dan pada tahun 2017 bulan April penulis melakukan Kuliah Kerja Nyata Terpadu Angkatan 114 di Kabupaten Minahasa Kecamatan Sonder tepatnya di Desa Rambunan (Rambunan Amian).

Pada tahun 2017 bulan Juli, penulis membuat Skripsi demi memenuhi syarat memperoleh gelar Sarjana (S1) dengan penelitian berjudul Analisa Pemanfaatan E-Learning Untuk Proses Pembelajaran, yang telah dibimbing oleh dua dosen pembimbing yaitu Dr. Eng. Sary D.E. Paturusi, ST., M.Eng Sherwin R.U.A. Sompie, ST., MT. sehingga pada tanggal 22 Januari 2018 penulis resmi lulus dari Program Studi Teknik Informatika Jurusan Elektro Fakultas Teknik Universitas Sam Ratulangi Manado dan menyandang gelar Sarjana Komputer dengan predikat Sangat Memuaskan. 